\title{
Effects of Osthol Isolated from Cnidium monnieri Fruit on Urate Transporter 1
}

\author{
Yuusuke Tashiro ${ }^{1}$, Ryo Sakai ${ }^{1}$, Tomoko Hirose-Sugiura ${ }^{2}$, Yukio Kato ${ }^{2}$, Hirotaka Matsuo ${ }^{3}$, \\ Tappei Takada ${ }^{4}$, Hiroshi Suzuki ${ }^{4}$ and Toshiaki Makino ${ }^{1, * \mathbb{C}}$ \\ 1 Department of Pharmacognosy, Graduate School of Pharmaceutical Sciences, Nagoya City University, \\ Nagoya 467-8603, Japan; ytashiro@sunprom.med.nagoya-cu.ac.jp (Y.T.); sakairyo0@gmail.com (R.S.) \\ 2 Faculty of Pharmacy, Institute of Medical, Pharmaceutical and Health Sciences, Kanazawa University, \\ Kanazawa 920-1192, Japan; tomoko.s@p.kanazawa-u.ac.jp (T.H.-S.); ykato@p.kanazawa-u.ac.jp (Y.K.) \\ 3 Department of Integrative Physiology and Bio-Nano Medicine, National Defense Medical College, \\ 3-2 Namiki, Tokorozawa, Saitama 359-8513, Japan; hmatsuo@ndmc.ac.jp \\ 4 Department of Pharmacy, The University of Tokyo Hospital, Faculty of Medicine, The University of Tokyo, \\ Tokyo 113-8655, Japan; tappei-tky@umin.ac.jp (T.T.); suzukihi-tky@umin.ac.jp (H.S.) \\ * Correspondence: makino@phar.nagoya-cu.ac.jp; Tel.: +81-52-836-3416
}

Received: 12 October 2018; Accepted: 29 October 2018; Published: 1 November 2018

\begin{abstract}
Background: Crude drugs used in traditional Japanese Kampo medicine or folk medicine are major sources of new chemical entities for drug discovery. We screened the inhibitory potential of these crude drugs against urate transporter 1 (URAT1) to discover new drugs for hyperuricemia. (2) Methods: We prepared the $\mathrm{MeOH}$ extracts of 107 different crude drugs, and screened their inhibitory effects on URAT1 by measuring the uptake of uric acid by HEK293/PDZK1 cells transiently transfected with URAT1. (3) Results: We found that the extract of the dried mature fruit of Cnidium monnieri inhibited urate uptake via URAT1. We isolated and identified osthol as the active ingredient from this extract. Osthol noncompetitively inhibited URAT1 with an $\mathrm{IC}_{50}$ of $78.8 \mu \mathrm{M}$. We evaluated the effects of other coumarins and found that the prenyl group, which binds at the 8-position of coumarins, plays an important role in the inhibition of URAT1. (4) Conclusions: Cnidium monnieri fruit may be useful for the treatment of hyperuricemia or gout in traditional medicine, and its active ingredient, osthol, is expected to be a leading compound for the development of new drugs for hyperuricemia.
\end{abstract}

Keywords: urate transporter 1; uric acid; traditional Japanese Kampo medicine; Cnidium monnieri; osthol; coumarins

\section{Introduction}

Hyperuricemia is a disease associated with lifestyle habits, and the increasing frequency of hyperuricemia and gout is most likely caused by westernized lifestyles and environments [1]. Hyperuricemia can be a risk factor not only for gouty arthritis and kidneys and ureteric stones, but also for cardiovascular and chronic kidney diseases [2,3]. Therefore, as an appropriate intervention, hyperuricemia should be tackled at an early stage [4].

Since humans have a nonfunctional urate oxidase gene, the blood concentration of uric acid, the end product of purine catabolism, is higher in humans than in other animals. In humans, the uric acid fraction that comes from foods or is synthesized from nucleosides is primarily excreted into the urine via glomerular filtration; however, most uric acid is reabsorbed by the proximal tubules via transporters. Another part of uric acid is excreted into the intestine via excretion-type transporters from the intestinal epithelial cells. Recent studies revealed that changes in the expression or functional changes in uric acid transporters are associated with hyperuricemia [5]. 
Urate transporter 1 (URAT1, SLC22A12) is expressed on the brush border membrane of proximal tubular cells, and is identified as the transporter that reabsorbs uric acid from the primary urine into the cells [6]. Apart from URAT1, glucose transporter 9 (GLUT9, SLC2A9), breast-cancer resistance protein ABCG2, organic anion transporter 1 and 3 (OAT1/3, SLC22A6/SLC22A8), multidrug resistance protein 4 (MRP4, ABCC4), and sodium phosphate transporter 4 (NPT4, SLC17A3) were identified as uric acid transporters, and these transporters play roles in the excretion of uric acid in the kidney and intestine [7-10].

Benzbromarone is a uricosuric agent and the first-line drug for the treatment of renal underexcretion-type hyperuricemia [1]. Benzbromarone increases the elimination of uric acid by the inhibition of URAT1 and uric acid reabsorption [6,11]. However, its usage is limited by its severe adverse effect in fulminant hepatitis [12]; thus, the discovery of safer URAT1 inhibitors is needed.

In this study, we screened new URAT1 inhibitors among 107 crude drugs used as components of formulations used in traditional Japanese Kampo medicine or as folk medicines. We identified osthol, the active ingredient of the fruit of Cnidium monnieri, as a promising lead compound for further drug-discovery efforts.

\section{Results}

\subsection{Screening of 107 Crude Drug Extracts}

In this study, we screened the inhibitory effects of 107 crude drug extracts on urate uptake via URAT1, and the results are presented in Figure 1. The crude drugs whose extracts exhibited an inhibitory effect on urate uptake with less than $50 \%$ of control at $100 \mu \mathrm{g} / \mathrm{mL}$ were Alpiniae Officinari Rhizoma, Amomi Semen, Araliae Cordatae Rhizoma, Arctii Fructus, Artemisiae Capillaris Flos, Atractylodis Rhizoma, Cimicifugae Rhizoma, Cinnamomi Cortex, Cnidii Monnieris Fructus, Cyperi Rhizoma, Schizonepetae Spica and Zingiberis Rhizoma Processum. Then, the cytotoxicities of these extracts were evaluated using the MTT assay. Finally, we observed that the extracts of Artemisiae Capillaris Flos, Cinnamomi Cortex, Cnidii Monnieris Fructus and Schizonepetae Spica exhibited an inhibitory effect of urate uptake with less than $50 \%$ of control without significant cytotoxicities at $100 \mu \mathrm{g} / \mathrm{mL}$.

\subsection{Effect of Cnidii Monnieris Fructus Extract on URAT1, and Its Activity-Guided Fractionation}

Among these four crude drugs, we chose Cnidii Monnieris Fructus for further evaluation since it exhibited the highest inhibitory effect on urate uptake via URAT1. The $\mathrm{MeOH}$ extract of Cnidii Monnieris Fructus inhibited urate uptake via URAT1 in a concentration-dependent manner with the half maximal inhibitory concentration ( $\mathrm{IC}_{50}$ ) of $53.2 \mu \mathrm{g} / \mathrm{mL}$ (Figure 2a). Cnidii Monnieris Fructus extract also exhibited a concentration-dependent cytotoxicity; however, cytotoxicity was not statistically significant at concentrations below $100 \mu \mathrm{g} / \mathrm{mL}$ (Figure $2 \mathrm{~b}$ ).

We tried to identify the active compound from Cnidii Monnieris Fructus. When the $\mathrm{MeOH}$ extract of Cnidii Monnieris Fructus was partitioned into four fractions, both hexane and AcOEt fractions exhibited significant inhibitory effects at concentrations equivalent to $100 \mu \mathrm{g} / \mathrm{mL}$ of the original extract (Figure 3). Since thin-layer chromatography (TLC) patterns of these two fractions contained the same spot, and since stronger signals were found for the hexane fraction than for the AcOEt fraction, the hexane fraction was further fractionated by open silica-gel chromatography into fraction A-N. Fractions D-H exhibited significant inhibitory effects on urate uptake via URAT1 at $33 \mu \mathrm{g} / \mathrm{mL}$ (D, 39\%; E, 35\%; F, 34\%; G, 33\%, H, 52\%). These fractions had a spot with identical $R f$ value in the patterns observed by TLC, and osthol was collected from this spot by preparative TLC and identified by the spectra of ${ }^{1} \mathrm{H}$ - and ${ }^{13} \mathrm{C}$ - nuclear magnetic resonance (NMR), electron ionization-mass spectrometry (EI-MS) spectra. Moreover, the same elution time was observed by high-performance liquid chromatography (HPLC) analysis when using the standard compound. The chemical structure of osthol is shown in Figure S1. 


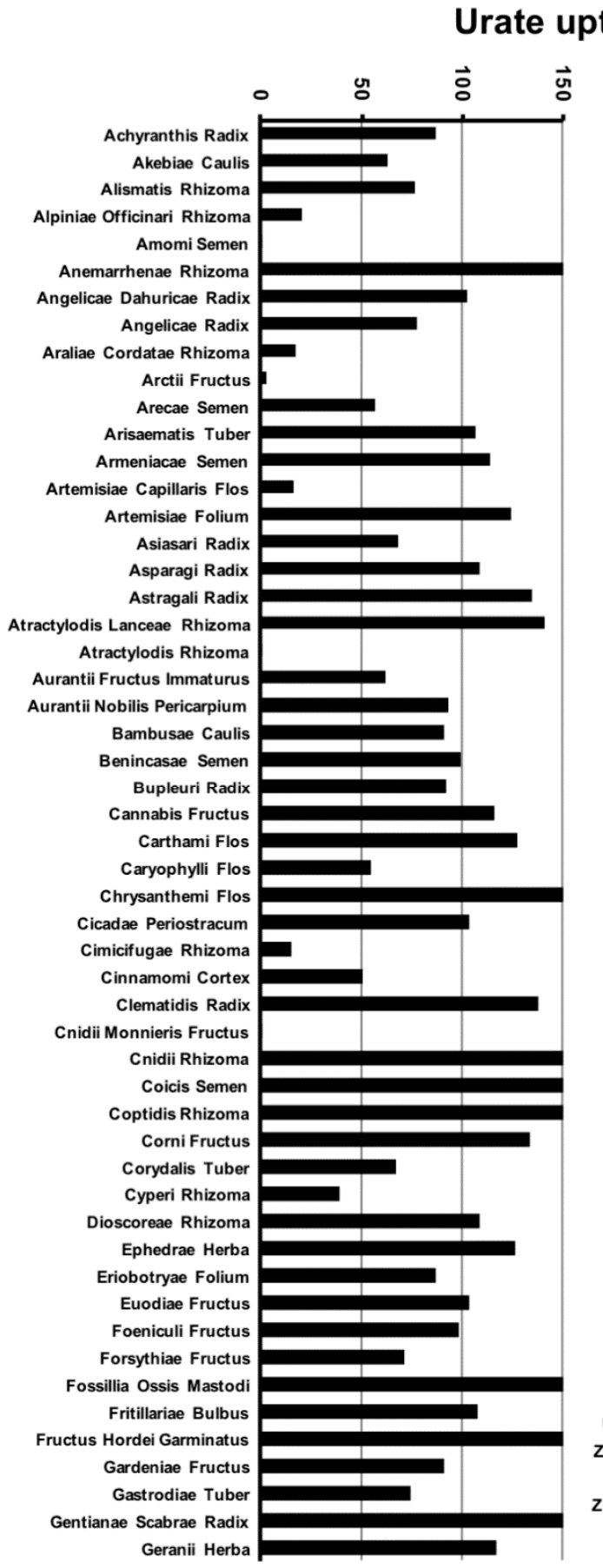

take (\% of control)

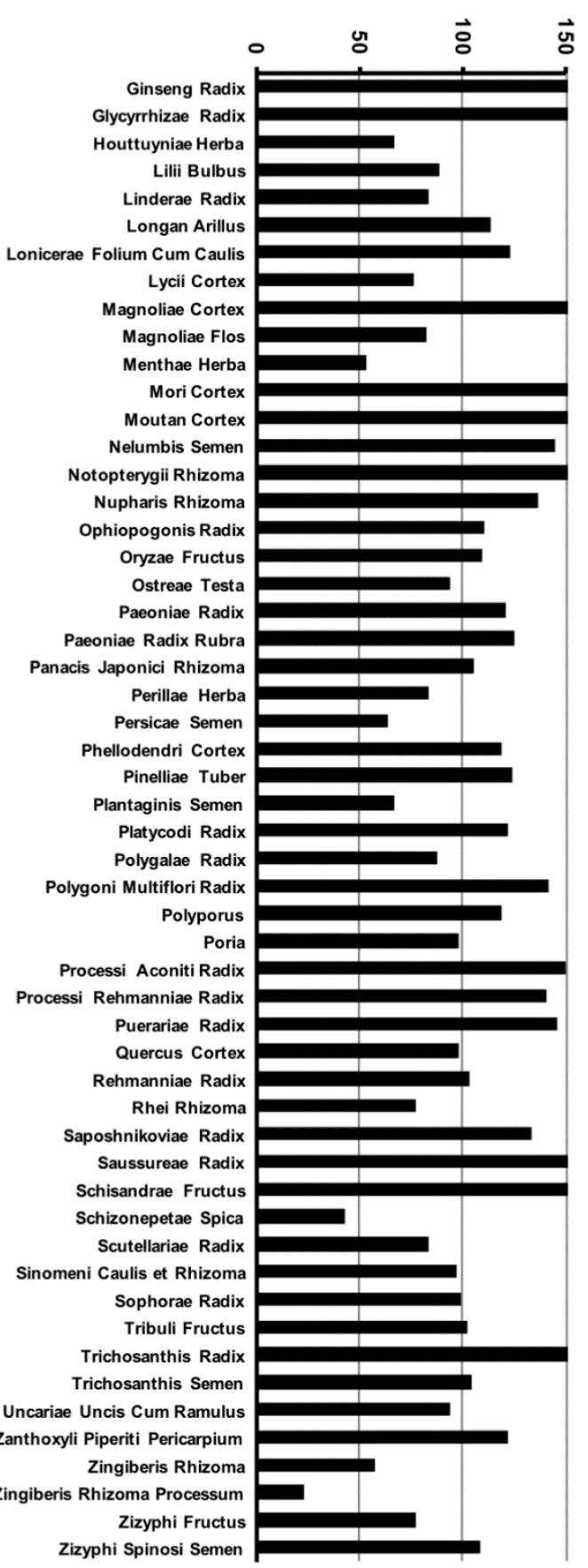

Figure 1. Effects of crude drug extracts on the uptake of uric acid via urate transporter 1 (URAT1). HEK293/PDZK1 cells were transiently transfected with human URAT1. The cells were incubated with uric acid $(11.6 \mu \mathrm{M})$ with or without each crude drug extract $(100 \mu \mathrm{g} / \mathrm{mL})$ at $37^{\circ} \mathrm{C}$ for $30 \mathrm{~min}$, and the uptakes of uric acid into the cells were measured. The origins of crude drugs are listed in Supplementary Table S1. Data are expressed as \% of control, calculated as described in Materials and Methods, and they represent averages of the experiments $(n=2)$. 


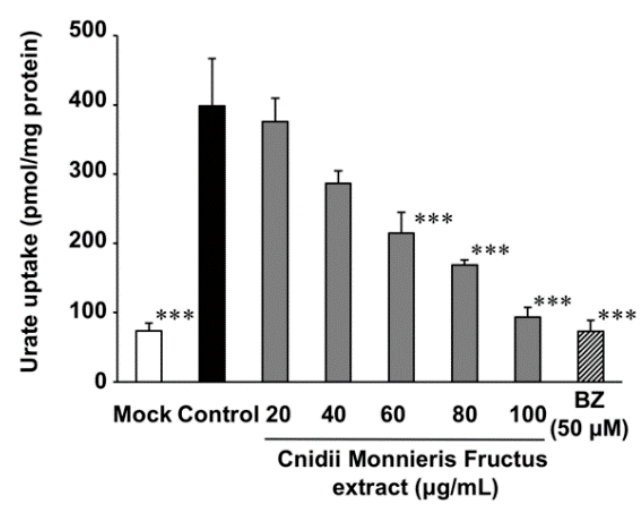

(a)

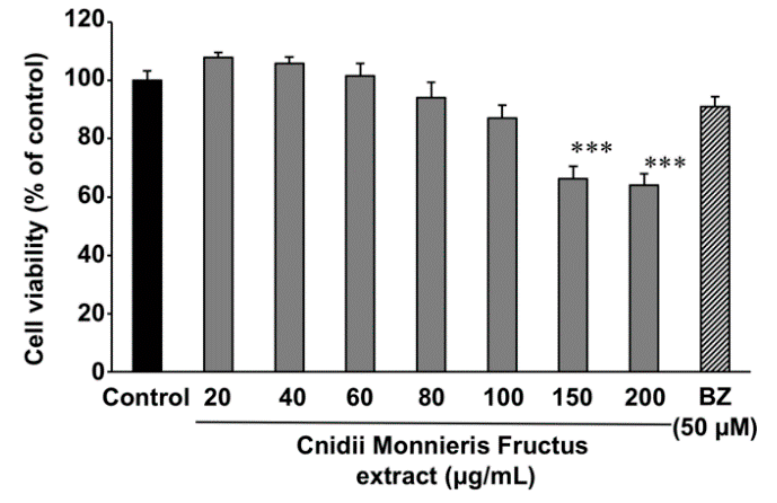

(b)

Figure 2. Effect of Cnidii Monnieris Fructus extract on the uptake of uric acid via URAT1. (a) HEK293/PDZK1 cells were transiently transfected with human URAT1. Cells were incubated with uric acid $(11.6 \mu \mathrm{M})$ with or without the extract at $37^{\circ} \mathrm{C}$ for $30 \mathrm{~min}$, and the uptakes of uric acid into the cells were measured. Data are expressed as the mean \pm S.E. $(n=3)$. (b) Cytotoxicity of Cnidii Monnieris Fructus extract was measured using the MTT method. Data are expressed as the mean \pm S.E. $(n=6)$. Benzbromarone $(\mathrm{BZ}, 50 \mu \mathrm{M})$ was used as a positive control. ${ }^{* * *} p<0.001$ vs. the control group by analysis of variance (ANOVA) and Bonferroni-Dunnett's multiple $t$-test.

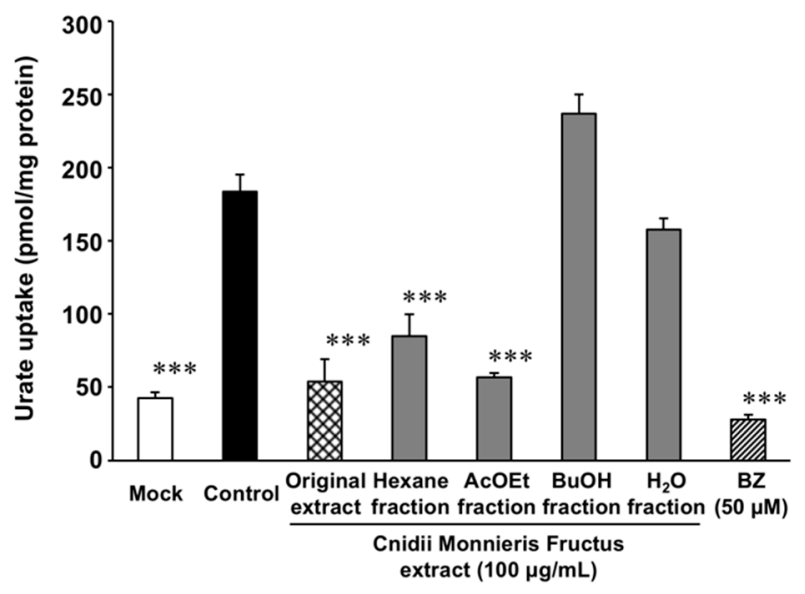

Figure 3. Effect of Cnidii Monnieris Fructus extract and its fractions on the uptake of uric acid via URAT1. HEK293/PDZK1 cells were transiently transfected with human URAT1. Cells were incubated with uric acid $(11.6 \mu \mathrm{M})$ with or without the extract and its fractions at the concentrations related to Cnidii Monnieris Fructus extract $(100 \mu \mathrm{g} / \mathrm{mL})$, respectively, at $37^{\circ} \mathrm{C}$ for $30 \mathrm{~min}$, and the uptakes of uric acid into the cells were measured. Data are expressed as the mean \pm S.E. $(n=3) .50 \mu \mathrm{M}$ of BZ was used as a positive control. ${ }^{* * *} p<0.001$ vs. the control group by ANOVA and Bonferroni-Dunnett's multiple $t$-test.

\subsection{Inhibitory Effect of Osthol on URAT1 and Its Kinetics}

Osthol inhibited urate uptake via URAT1 in a concentration-dependent manner, and its $\mathrm{IC}_{50}$ value was $78.8 \mu \mathrm{M}$ (Figure 4a). Osthol exhibited a concentration-dependent cytotoxicity, but it was not significant at the concentrations below $100 \mu \mathrm{M}$ (Figure $4 \mathrm{~b}$ ). The concentration of osthol in the $\mathrm{MeOH}$ extract of Cnidii Monnieris Fructus was $28.3(w / w) \%$ as determined by HPLC analysis.

Kinetic analysis of the inhibitory effects of osthol on URAT1 was performed. The uptake of urate $(25,50,100$, and $200 \mu \mathrm{M})$ was measured with or without $100 \mu \mathrm{M}$ of osthol for $1 \mathrm{~min}$, and a Lineweaver-Burk plot was plotted (Figure 5). Two regression lines were crossed on the X-axis. 


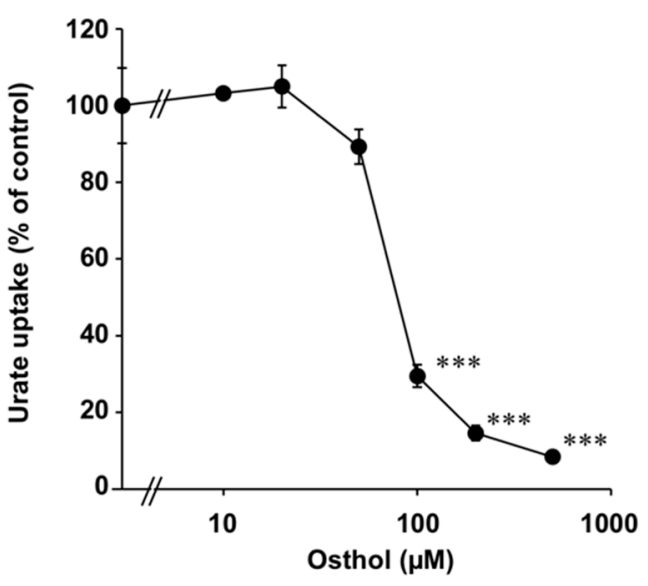

(a)

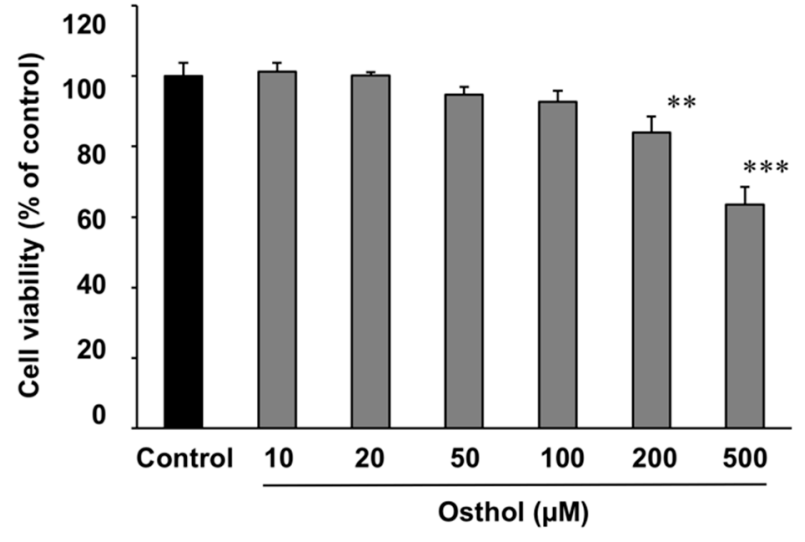

(b)

Figure 4. Effect of osthol on the uptake of uric acid via URAT1. (a) HEK293/PDZK1 cells were transiently transfected with human URAT1. Cells were incubated with uric acid $(11.6 \mu \mathrm{M})$ with or without osthol at $37^{\circ} \mathrm{C}$ for $30 \mathrm{~min}$, and the uptakes of uric acid into the cells were measured. Data are expressed as the mean \pm S.E. $(n=3)$. (b) Cytotoxicity of osthol was measured using the MTT method. Data are expressed as the mean \pm S.E. $(n=6) .{ }^{* *} p<0.01$ and ${ }^{* * *} p<0.001$ vs. the control group by ANOVA and Bonferroni-Dunnett's multiple $t$-test.

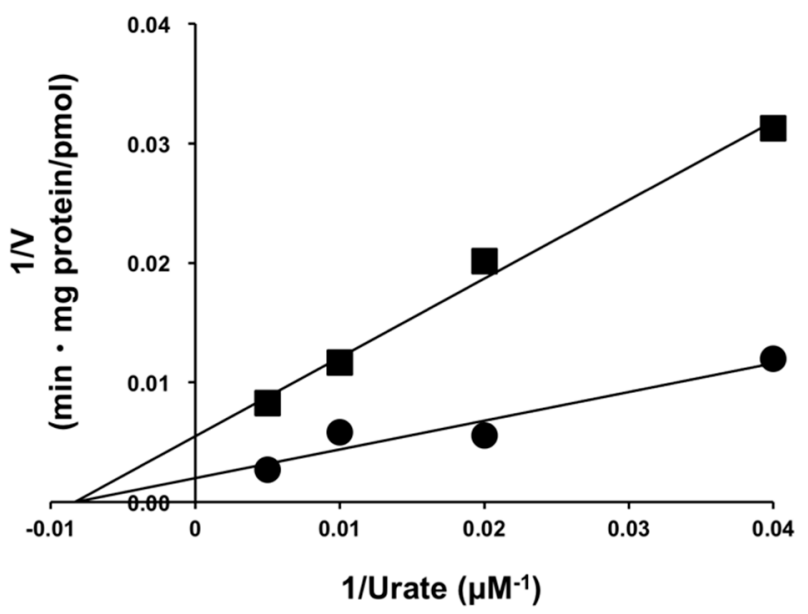

Figure 5. Kinetics analysis for the inhibitory effect of osthol on the uptake of uric acid via URAT1. HEK293/PDZK1 cells were transiently transfected with human URAT1. The cells were incubated with uric acid $(25,50,100$, and $200 \mu \mathrm{M})$ with (closed square) or without (closed circle) osthol $(100 \mu \mathrm{M})$ at $37^{\circ} \mathrm{C}$ for $1 \mathrm{~min}$. The uptakes of uric acid into the cells (V) were measured, and a Lineweaver-Burk plot was made. Each symbol is expressed as the mean of quadruplicate data. Linear regression lines calculated using the least-square method are shown.

\subsection{Comparison of Inhibitory Effects on URAT1 among Coumarins}

The inhibitory effects of coumarins (Figure S1) were compared. Although coumarins, which have a basic structure, did not exhibit clear inhibitory effects, osthol and osthenol, which have an 8-prenyl group, exhibited a significant inhibitory effect on URAT1 at $100 \mu \mathrm{M}$. Bergaptol and bergamottin, which belong to furanocoumarins, and geraniol, which is a basic compound containing a prenyl group, did not inhibit URAT1 (Table 1). 
Table 1. Inhibitory effect of the related compounds of osthol on the uptake of urate via URAT1.

\begin{tabular}{cc}
\hline Compound & Urate Uptake (\% of Control) \\
\hline coumarin & $111 \pm 8$ \\
7-methoxycoumarin & $137 \pm 8$ \\
4-hydroxycoumarin & $87 \pm 9$ \\
6-hydroxycoumarin & $83 \pm 14$ \\
umbelliferone & $114 \pm 6$ \\
daphnetin & $140 \pm 10$ \\
esculetin & $120 \pm 5$ \\
fraxetin & $136 \pm 7$ \\
osthol & $36 \pm 10$ \\
osthenol & $31 \pm 4$ \\
bergaptol & $83 \pm 6$ \\
bergamottin & $117 \pm 6$ \\
geraniol & $88 \pm 5$
\end{tabular}

HEK293/PDZK1 cells were transiently transfected with human URAT1, and incubated with $0.625 \mu \mathrm{Ci} / \mathrm{ml}\left[\mathrm{8}^{14} \mathrm{C}\right]$ uric acid with or without each compound $(100 \mu \mathrm{M})$ for $30 \mathrm{~min}$. Then, the uptakes of radioactivity into the cells were measured. Data are expressed as mean \pm S.E. $(n=3-4)$. Data are expressed as $\%$ of control calculated as described in the Materials and Methods.

\section{Discussion}

URAT1 exists at the brush border membrane of renal proximal tubular cells and reabsorbs uric acid from the primary urine into the blood circulation. It can be regarded as a pre-eminent target in drug discovery, as observed for the previous efforts that led to the discovery of enhancers of uric acid elimination, such as benzbromarone, probenecid [6], and lesinurad [13]. The activity of uric acid transportation via URAT1 in vitro can be evaluated by a Xenopus laevis oocyte induced with URAT1 or by vesicles of renal brush border membrane [6,14]. In HEK293 cells, the dual transfection of URAT1 and its anchor protein PDZK1 exhibited higher uptake of uric acid than the single transfection of URAT1 [15]. In the present study, we screened URAT1 inhibitors from 107 crude drugs used in traditional Japanese Kampo medicines and as folk medicines using HEK293/PDZK1 cells transiently transfected with URAT1, and found that the extract of Cnidii Monnieris Fructus and its active ingredient, osthol, significantly inhibited URAT1.

Cnidii Monnieris Fructus is originated from the dried mature fruit of Cnidium monnieri (Apiaceae), and it is used to disperse cold, dispel wind, dry dampness, warm the kidneys, fortify the yang, kill parasites, and stop itching in traditional Chinese medicine [16], and to treat skin sores, tinea, and itching as external medication in traditional Japanese Kampo medicine [17]. An experimental pharmacological study revealed that its extract exhibited immunostimulant [18], anti-inflammatory [19], antiallergic, antipruritic [20,21], and antiosteoporotic effects [22]. However, there are no reports of the usages of Cnidii Monnieris Fructus for hyperuricemia or gout in traditional medicines. Since Cnidii Monnieris Fructus (Shechuangzi in Chinese) is an approved drug in China [23], it is expected that this crude drug can also be used for the treatment of hyperuricemia or gout.

In the present study, the $\mathrm{IC}_{50}$ values of Cnidii Monnieris Fructus extract and osthol for urate uptake via URAT1 were 53.2 and $19.2 \mu \mathrm{g} / \mathrm{mL}(=28.5 \mu \mathrm{M})$, respectively. Since the extract at the $\mathrm{IC}_{50}$ value contained $15.1 \mu \mathrm{g} / \mathrm{mL}$ of osthol, osthol was responsible for $79 \%$ of the inhibitory effect of the extract. It is suggested that osthol could be considered the major active ingredient of Cnidii Monnieris Fructus extract for the inhibition of URAT1, and can be used as the marker compound for the quality control of enhancers of uric acid elimination.

Among natural products, it is reported that morin, one of the flavonoids isolated from the twigs of Morus alba, competitively inhibits URAT1 [24]. In this study, we did not evaluate the twigs of $M$. $a l b a$; instead, we evaluated the root bark of M. alba because the twig of this plant is not used as a crude drug in Japan. Chang et al. reported that EtOH extracts of the twigs or root bark of M. alba contained $21 \mathrm{mg} / \mathrm{g}$ of morin in both [25]. Although the MeOH extract of root bark of M. alba (Mori 
Cortex) in this study contained morin at some extent, in our screening experiment, we did not observe an inhibitory effect of M. alba root bark extract on URAT1. On the contrary, not only did M. alba root bark extract but some crude drug extracts stimulate the uptake of uric acid into the cells. Although the detailed mechanisms by which extracts increase uric acid uptake are unknown, we cannot exclude their possible effects on transporters other than URAT1, or on the expression and/or translocation of URAT1, since uptake studies did not focus on the initial phase of the uptake, but were performed for a relatively longer period (30 $\mathrm{min})$.

We evaluated the inhibitory effects of coumarins on URAT1, and found that 8-prenyl coumarins, including osthol and osthenol, significantly inhibited URAT1. Since bergamottin, which is a 5-O-prenyl coumarin, and the simple prenyl compound geraniol did not inhibit URAT1, we postulated that the prenyl group taht binds at the 8-position of coumarins would play an important role in the inhibition of URAT1. Osthol was the noncompetitive inhibitor of URAT1 in the present study. Since uric acid is a heterocyclic compound without any prenyl groups, osthol could not compete with uric acid; instead, it could bind to an allosteric pocket of URAT1 to inhibit its function. Among coumarin derivatives, esculetin and fraxetin lowered the serum concentration of uric acid after oral administration in murine hyperuricemia models induced by oxonate [26]. However, esculetin and fraxetin did not inhibit URAT1 in the present study. Since esculetin and fraxetin restored the expressions of transporters of uric acid in the kidney, such as OAT1 and ABCG2 [24], osthol might act on these transporters to improve hyperuricemia, since osthol presents the basic chemical structure of coumarins, similar to esculetin and fraxetin.

Osthol was recently reported to show anticancer [27], cardioprotective [28-30], antihypertensive [29], anti-inflammatory, and antiasthma [31] properties, to suppress ulcerous colitis [32], to promote bone-fracture healing [33], to induce osteogenesis in osteoblasts [34], to protect chronic [35] and acute kidney failure [36], and to inhibit intimal hyperplasia [37]. In the present study, osthol exhibited a URAT1-inhibitory effect $\left(\mathrm{IC}_{50}=78.8 \mu \mathrm{M}\right)$ compatible with that of probenecid and indomethacin, whose $\mathrm{IC}_{50}$ values were 42 and $41 \mu \mathrm{M}$, respectively [11]. Though the $\mathrm{IC}_{50}$ value of osthol was larger than that of benzbromarone (less than $0.1 \mu \mathrm{M})$ [6] and lesinrad (3.5 $\mu \mathrm{M})$ [38], there are no reports for Cnidii Monnieris Fructus causing liver injury, and osthol could not have the adverse effect of liver injury [12]. Therefore, we suggest that Cnidii Monnieris Fructus may be useful for the treatment of hyperuricemia or gout in traditional medicine, and that osthol can be used as a leading compound for drug discovery for hyperuricemia and gout. Further studies to validate osthol activity in vivo are needed.

\section{Materials and Methods}

\subsection{Crude Drugs}

We chose 107 crude drugs that are frequently used as ingredients in traditional Japanese Kampo formulations or as folk medicines in Japan, and purchased the crude drugs that met the grade standards of the Japanese Pharmacopoeia (17th Edition) [39] or of nonpharmacopoeial crude drugs (2015) [40] from several distributers (Table S1). Five grams of each crude drug was sonicated in $100 \mathrm{~mL}$ of $\mathrm{MeOH}$ for $30 \mathrm{~min}$ and filtered. The residue was further extracted twice in the same manner, the three filtrates were merged, evaporated under reduced pressure, and finally lyophilized to yield the final crude extract. The Latin names, origins, lot numbers, and the extraction ratios yielded from each crude drug are shown in Table S1. Each extract was suspended in dimethylsulfoxide at a concentration of $100 \mathrm{mg} / \mathrm{mL}$, and kept at $-20{ }^{\circ} \mathrm{C}$ until use.

\subsection{Inhibitory Effect of the Samples on URAT1}

HEK293 cells stably expressing the myc construct of PDZK1 (HEK293/PDZK1 cells) were previously obtained [41]. HEK293/PDZK1 cells were maintained in Dulbecco's modified Eagle's medium (Sigma-Aldrich, St. Louis, MO, USA) containing 10\% fetal bovine serum (FBS, Invitrogen, 
Carlsbad, CA, USA) and $1 \mathrm{mg} / \mathrm{mL}$ G418 disulfate (Nacalai Tesque, Kyoto, Japan) in a humidified incubator at $37^{\circ} \mathrm{C}$ under a $5 \% \mathrm{CO}_{2}$ atmosphere. The cells were seeded in poly-L-lysine-coated 24-well plates $\left(2.5 \times 10^{5}\right.$ cells/well) and incubated for $24 \mathrm{~h}$. cDNA-encoding human URAT1 was subcloned into the pCMV-SPORT6 vector (Invitrogen). The constructs were transfected into HEK293/PDZK1 cells using a cationic liposome prepared with Hilly Max reagent (Dojindo Laboratories, Kumamoto, Japan) according to the manufacturer's protocol. For mock cells, the pCMV-SPORT6 vector was transfected into the cells. Then, the cells were further incubated for $24 \mathrm{~h}$. The transfected cells were preincubated for $7.5 \mathrm{~min}$ at $37^{\circ} \mathrm{C}$ with $0.2 \mathrm{~mL}$ of chloride-free Hanks' balanced salt solution $\left(\mathrm{Cl}^{-}\right.$-free HBSS; $125 \mathrm{mM}$ gluconic acid sodium salt, $4.8 \mathrm{mM}$ potassium gluconate, $1.3 \mathrm{mM}$ calcium gluconate, $1.2 \mathrm{mM} \mathrm{KH}_{2} \mathrm{PO}_{4}, 1.2 \mathrm{mM} \mathrm{MgSO}_{4}, 5.6 \mathrm{mM}$ glucose, $\mathrm{pH}$ 7.4). $\mathrm{Cl}^{-}$-free HBSS containing $0.625 \mu \mathrm{Ci} / \mathrm{mL}$ $(=11.6 \mu \mathrm{M}=0.2 \mathrm{mg} / \mathrm{dL})\left[8^{-14} \mathrm{C}\right]$ uric acid (American Radiolabeled Chemicals, St. Louis, MO, USA) with or without the samples were prepared, and the cells were incubated at $37^{\circ} \mathrm{C}$ with $0.25 \mathrm{~mL}$ of these solutions for $30 \mathrm{~min}$. Benzbromarone (Sigma) was used as positive control. The final concentration of DMSO in the medium was $0.1 \%$ or less. For kinetic analysis, $\left[8-{ }^{14} \mathrm{C}\right]$ uric acid was diluted with cold uric acid to a suitable concentration, and the incubation time was set at $1 \mathrm{~min}$. The cells were washed three times with ice-cold PBS, and then $0.2 \mathrm{~mL}$ of $1 \mathrm{M} \mathrm{NaOH}$ was added. The plates were incubated overnight under gentle shaking, and the cell lysates were neutralized with $0.2 \mathrm{~mL}$ of $1 \mathrm{M} \mathrm{HCl}$. An aliquot $(20 \mu \mathrm{L})$ of the solution was used for protein analysis, and the remaining solutions were transferred into vials containing $4 \mathrm{~mL}$ of Clearzol I (Nacalai). Radioactivities were measured using a liquid scintillation counter. Protein concentrations were measured using a BCA ${ }^{\mathrm{TM}}$ Protein Assay kit (Thermo Scientific, Rockford, IL, USA). The uptake amount of uric acid into the cells was compensated by the amount of protein, and the percentage of the control for uric acid uptake by URAT1 was calculated as follows:

Uptake of uric acid (\% of control) $=($ (uptake into sample-treated URAT1-transfected cells $)-$ (uptake into mock cells))/((uptake into control URAT1-transfected cells) - (uptake into mock cells)) $\times 100$.

$\mathrm{IC}_{50}$ was calculated from the least-square regression line made from three points that crossed $50 \%$ of the control logarithmic concentration values.

\subsection{Sample Cytotoxicity}

HEK293/PDZK1 cells were seeded in 96-well plates $\left(5 \times 10^{4}\right.$ cells/well $)$ and incubated for $24 \mathrm{~h}$. Then, the cells were incubated with Cl-free HBSS containing the sample for $30 \mathrm{~min}$. The solutions were aspirated, and the cells were further incubated with a medium containing $10 \%$ FBS for $2 \mathrm{~h}$. Then, the cells were incubated with a medium containing 3-(4,5-dimethylthiazol-2-yl)-2,5-diphenyl tetrazolium bromide $(0.5 \mathrm{mg} / \mathrm{mL}$; MTT, Sigma), and further incubated for $4 \mathrm{~h}$. Following this, $10 \%$ sodium lauryl sulfate solution was added to the wells, and the plate was incubated for $20 \mathrm{~h}$ to dissolve formazan crystals produced by the cells. Optical density at $570 \mathrm{~nm}\left(\mathrm{OD}_{570}\right)$ was measured, and cell viability was calculated as follows:

Cell viability $(\%$ of control $)=\left(\left(\mathrm{OD}_{570}\right.\right.$ of sample-treated cells $)-\left(\mathrm{OD}_{570}\right.$ of the background $\left.)\right) /$ $\left(\left(\mathrm{OD}_{570}\right.\right.$ of control cells $)-\left(\mathrm{OD}_{570}\right.$ of the background $\left.)\right) \times 100$.

\subsection{Preparation and Fractionation of Cnidii Monnieris Fructus Extract}

Cnidii Monnieris Fructus (100 g; Lot \#23610001, Tochimoto Tenkaido, Osaka, Japan) was sonicated in $0.7 \mathrm{~L}$ of $\mathrm{MeOH}$ for $30 \mathrm{~min}$ and filtered. The remaining residue was further twice extracted with $\mathrm{MeOH}$; the resulting filtrates were combined, evaporated under reduced pressure, and lyophilized to yield the crude extract. This protocol was repeated four times, each with $100 \mathrm{~g}$ of Cnidii Monnieris Fructus. Altogether, $26.1 \mathrm{~g}$ of MeOH extract was obtained from $500 \mathrm{~g}$ of Cnidii Monnieris Fructus. This extract was suspended in $1.05 \mathrm{~L}$ of $\mathrm{H}_{2} \mathrm{O}$, and was extracted with $450 \mathrm{~mL}$ of hexane (three times) to yield the hexane fraction. The water layer was extracted again with $450 \mathrm{~mL}$ of AcOEt (three times), and then extracted with $450 \mathrm{~mL}$ of water-saturated $\mathrm{BuOH}$ (three times). The hexane, $\mathrm{AcOEt}, \mathrm{BuOH}$, and water fractions yielded 6.1, 7.4, 2.3, and $2.5 \mathrm{~g}$ of crude extract, respectively. 
The hexane crude fraction (3.0 g) was applied to open silica-gel chromatography (BW-200, Fuji Silysia, Kasugai, Japan; 5.5 i.d. $\times 22.5 \mathrm{~cm}$ ) eluted with hexane:acetone (8:2). Factions A $(79 \mathrm{mg})$, B (379 mg), C (211 mg), D (536 mg), E (44 mg), F (581 mg), G (865 mg), H (460 mg), I (250 mg), J (83 mg), $\mathrm{K}(107 \mathrm{mg}), \mathrm{L}(75 \mathrm{mg}), \mathrm{M}(140 \mathrm{mg})$, and N (130 mg) were collected from the crude mixture following the pattern observed by TLC (Figure S2). Fraction F $(150 \mathrm{mg})$ was applied to preparative TLC (PLC silica gel $60 \mathrm{~F}_{254}, 0.5 \mathrm{~mm}$, Merck, Darmstadt, Germany) developed with hexane:acetone (6:4). The spot with $R f$ value 0.5 detected by the absorbance at $254 \mathrm{~nm}$ was collected to yield compound $\mathbf{1}(12 \mathrm{mg})$. The ${ }^{1} \mathrm{H}$ - and ${ }^{13} \mathrm{C}-\mathrm{NMR}$ ), and EI-MS spectra of compound 1 matched the ones previously described for osthol (Basile et al., 2009). The standard compound of osthol was purchased from LKT Laboratories Inc. (St. Paul, MN, USA; Lot \#: 23927906), and HPLC analysis (column, Cosmosil 5C C8$_{18}$-ARII, $4.6 \times 150 \mathrm{~mm}$, Nacalai Tesque, Kyoto, Japan; Solvent A (0.1\% HCOOH)/B (MeOH) 70/30-0/100 (0-20 min), $1.0 \mathrm{~mL} / \mathrm{min}$, linear gradient; detection, UV at $322 \mathrm{~nm}$ ) was conducted. compound $\mathbf{1}$ and osthol standard were eluted at $17.2 \mathrm{~min}$, and the mixed solution of compound $\mathbf{1}$ and osthol standard exhibited a single peak. From these results above, compound $\mathbf{1}$ was identified as osthol.

Osthol $(0.100,0.200$, and $0.400 \mu \mathrm{g}$, respectively) and Cnidii Monnieris Fructus $\mathrm{MeOH}$ extract $(1.00 \mu \mathrm{g})$ were applied to HPLC analysis following the protocol described above, and the concentration of osthol in the extract was calculated by the absolute calibration line $\left(r^{2}>0.999\right)$ obtained from the peak areas of osthol solution.

\subsection{Coumarins}

Standard compounds of coumarins were purchased as follows: coumarin (Nacalai), 7-methoxycoumarin (Tokyo Chemical Industry, Tokyo, Japan), 4-methoxycoumarin (Wako Pure Chemicals, Osaka, Japan), 6-methoxycoumarin (Wako), umbelliferone (Wako), daphnetin (Wako), esculetin (Wako), fraxetin (Sigma), bergaptol (Extrasynthese, Geray, France), bergamottin (ChromaDex, Irvine, CA, USA), osthenol (ChemFaces, Wuhan, China), and geraniol (Kanto Chemical Industry, Tokyo, Japan).

\subsection{Statistical Analysis}

Statistical analysis was carried out by one-way analysis of variance (ANOVA) and Dunnett's multiple comparison $t$-test using PASW Statistics software (version 18, SPSS; IBM, Armonk, NY, USA). A probability value of less than 0.05 was considered statistically significant.

Supplementary Materials: The following are available online at http:/ / www.mdpi.com/1420-3049/23/11/2837/ s1. Figure S1: Chemical structures of the compounds used as samples in this study; Figure S2: TLC pattern of the fractions collected from the hexane crude fraction. The hexane crude fraction $(3.0 \mathrm{~g})$ was applied to open silica gel chromatography eluted with hexane:acetone (8:2), and the fractions A-N were collected. Each fraction ( $3 \mu \mathrm{g})$ was spotted to TLC plate, spread out with hexane:acetone (8:2), and colored with anisaldehyde reagent. "Original" means the original hexane crude fraction. Large single spot in the fraction F is osthol; Table S1: The origin, distributer name, lot number of the sample, and the ratio yielded of crude drugs used.

Author Contributions: Y.T. and R.S. made extracts and evaluated the activities. T.H.-S. and Y.K. made HEK293 cells to stably express PDZK1. H.M., T.T. and H.S. taught and advised the experiments to Y.T. and R.S. T.M. presided over the study and wrote the article.

Funding: This study is supported by the Health Labor Sciences Research Grant (2010-General-011) from the Health, Labor, and Welfare Ministry, Japanese Government.

Conflicts of Interest: The authors declare no conflict of interest.

\section{References}

1. Yamanaka, H. Guideline for the Management of Hyperuricemia and Gout; Guideline Revision Committee: Tokyo, Japan, 2010. 
2. Redon, P.; Maloberti, A.; Facchetti, R.; Redon, J.; Lurbe, E.; Bombelli, M.; Mancia, G.; Grassi, G. Gender-related differences in serum uric acid in treated hypertensive patients from central and east European countries: Findings from the blood pressure control rate and cardiovascular risk profile study. J. Hypertens. 2018. [CrossRef] [PubMed]

3. Maloberti, A.; Maggioni, S.; Occhi, L.; Triglione, N.; Panzeri, F.; Nava, S.; Signorini, S.; Falbo, R.; Casati, M.; Grassi, G.; et al. Sex-related relationships between uric acid and target organ damage in hypertension. J. Clin. Hypertens. 2018, 20, 193-200. [CrossRef] [PubMed]

4. Kuwabara, M. Hyperuricemia, cardiovascular disease, and hypertension. Pulse 2016, 3, 242-252. [CrossRef] [PubMed]

5. Xu, L.; Shi, Y.; Zhuang, S.; Liu, N. Recent advances on uric acid transporters. Oncotarget 2017, 8, 100852-100862. [CrossRef] [PubMed]

6. Enomoto, A.; Kimura, H.; Chairoungdua, A.; Shigeta, Y.; Jutabha, P.; Cha, S.H.; Hosoyamada, M.; Takeda, M.; Sekine, T.; Igarashi, T.; et al. Molecular identification of a renal urate anion exchanger that regulates blood urate levels. Nature 2002, 417, 447-452. [CrossRef] [PubMed]

7. Anzai, N.; Ichida, K.; Jutabha, P.; Kimura, T.; Babu, E.; Jin, C.J.; Srivastava, S.; Kitamura, K.; Hisatome, I.; Endou, H.; et al. Plasma urate level is directly regulated by a voltage-driven urate efflux transporter URATv1 (SLC2A9) in humans. J. Biol. Chem. 2008, 283, 26834-26838. [CrossRef] [PubMed]

8. Eraly, S.A.; Vallon, V.; Rieg, T.; Gangoiti, J.A.; Wikoff, W.R.; Siuzdak, G.; Barshop, B.A.; Nigam, S.K. Multiple organic anion transporters contribute to net renal excretion of uric acid. Physiol. Genom. 2008, 33, 180-192. [CrossRef] [PubMed]

9. Jutabha, P.; Anzai, N.; Kitamura, K.; Taniguchi, A.; Kaneko, S.; Yan, K.; Yamada, H.; Shimada, H.; Kimura, T.; Katada, T.; et al. Human sodium phosphate transporter 4 (hNPT4/SLC17A3) as a common renal secretory pathway for drugs and urate. J. Biol. Chem. 2010, 285, 35123-35132. [CrossRef] [PubMed]

10. Matsuo, H.; Takada, T.; Ichida, K.; Nakamura, T.; Nakayama, A.; Ikebuchi, Y.; Ito, K.; Kusanagi, Y.; Chiba, T.; Tadokoro, S.; et al. Common defects of ABCG2, a high-capacity urate exporter, cause gout: A function-based genetic analysis in a Japanese population. Sci. Transl. Med. 2009, 1. [CrossRef] [PubMed]

11. Shin, H.J.; Takeda, M.; Enomoto, A.; Fujimura, M.; Miyazaki, H.; Anzai, N.; Endou, H. Interactions of urate transporter URAT1 in human kidney with uricosuric drugs. Nephrology 2011, 16, 156-162. [CrossRef] [PubMed]

12. Stamp, L.K.; Haslett, J.; Frampton, C.; White, D.; Gardner, D.; Stebbings, S.; Taylor, G.; Grainger, R.; Kumar, R.; Kumar, S.; et al. The safety and efficacy of benzbromarone in gout in Aotearoa New Zealand. Intern. Med. J. 2016, 46, 1075-1080. [CrossRef] [PubMed]

13. Cai, W.; Wu, J.; Liu, W.; Xie, Y.; Liu, Y.; Zhang, S.; Xu, W.; Tang, L.; Wang, J.; Zhao, G. Systematic structure-activity relationship (SAR) exploration of diarylmethane backbone and discovery of a highly potent novel uric acid transporter 1 (URAT1) inhibitor. Molecules 2018, 23, 252. [CrossRef] [PubMed]

14. Sato, M.; Wakayama, T.; Mamada, H.; Shirasaka, Y.; Nakanishi, T.; Tamai, I. Identification and functional characterization of uric acid transporter Urat1 (Slc22a12) in rats. Biochim. Biophys. Acta 2011, 1808, 1441-1447. [CrossRef] [PubMed]

15. Anzai, N.; Miyazaki, H.; Noshiro, R.; Khamdang, S.; Chairoungdua, A.; Shin, H.J.; Enomoto, A.; Sakamoto, S.; Hirata, T.; Tomita, K.; et al. The multivalent PDZ domain-containing protein PDZK1 regulates transport activity of renal urate-anion exchanger URAT1 via its C terminus. J. Biol. Chem. 2004, 279, 45942-45950. [CrossRef] [PubMed]

16. Bensky, D.; Clavey, S.; Stöger, E. Chinese Herbal Medicine-Materia Medica, 3rd ed.; Eastland Press: Seattle, WA, USA, 2004.

17. Japan Kampo Medicines Manufacturers' Association. Handbook on OTC Medicinal Product in Kampo; Jiho: Tokyo, Japan, 2013.

18. Malla, B.; Chang, B.Y.; Kim, S.B.; Park, H.; Lee, M.K.; Kim, S.Y. Potential of the Cnidium monnieri fruits as an immune enhancer in Escherichia coli infection model. J. Pharm. Pharmacol. 2016, 68, 1430-1439. [CrossRef] [PubMed]

19. Kwak, H.G.; Lim, H.B. Inhibitory effects of Cnidium monnieri fruit extract on pulmonary inflammation in mice induced by cigarette smoke condensate and lipopolysaccharide. Chin. J. Nat. Med. 2014, 12, 641-647. [CrossRef] 
20. Matsuda, H.; Ido, Y.; Hirata, A.; Ino, Y.; Naruto, S.; Amamiya, T.; Kubo, M. Antipruritic effect of Cnidii Monnieri Fructus (fruits of Cnidium monnieri CUSSON). Biol. Pharm. Bull. 2002, 25, 260-263. [CrossRef] [PubMed]

21. Matsuda, H.; Tomohiro, N.; Ido, Y.; Kubo, M. Anti-allergic effects of cnidii monnieri fructus (dried fruits of Cnidium monnieri) and its major component, osthol. Biol. Pharm. Bull. 2002, 25, 809-812. [CrossRef] [PubMed]

22. Zhang, Q.; Qin, L.; He, W.; Van Puyvelde, L.; Maes, D.; Adams, A.; Zheng, H.; De Kimpe, N. Coumarins from Cnidium monnieri and their antiosteoporotic activity. Planta Med. 2007, 73, 13-19. [CrossRef] [PubMed]

23. Chinese Pharmacopoeia Commission. Pharmacopoeia of the People's Republic of China, 1st ed.; The Stationery Office: Beijing, China, 2017.

24. Yu, Z.; Fong, W.P.; Cheng, C.H. Morin (3,5,7,2' , $4^{\prime}$-pentahydroxyflavone) exhibits potent inhibitory actions on urate transport by the human urate anion transporter (hURAT1) expressed in human embryonic kidney cells. Drug Metab. Dispos. 2007, 35, 981-986. [CrossRef] [PubMed]

25. Chang, L.W.; Juang, L.J.; Wang, B.S.; Wang, M.Y.; Tai, H.M.; Hung, W.J.; Chen, Y.J.; Huang, M.H. Antioxidant and antityrosinase activity of mulberry (Morus alba L.) twigs and root bark. Food Chem. Toxicol. 2011, 49, 785-790. [CrossRef] [PubMed]

26. Li, J.M.; Zhang, X.; Wang, X.; Xie, Y.C.; Kong, L.D. Protective effects of cortex fraxini coumarines against oxonate-induced hyperuricemia and renal dysfunction in mice. Eur. J. Pharmacol. 2011, 666, 196-204. [CrossRef] [PubMed]

27. Shokoohinia, Y.; Jafari, F.; Mohammadi, Z.; Bazvandi, L.; Hosseinzadeh, L.; Chow, N.; Bhattacharyya, P.; Farzaei, M.H.; Farooqi, A.A.; Nabavi, S.M.; et al. Potential anticancer properties of osthol: A comprehensive mechanistic review. Nutrients 2018, 10, 36. [CrossRef] [PubMed]

28. Li, Y.; Li, Y.; Shi, F.; Wang, L.; Li, L.; Yang, D. Osthole attenuates right ventricular remodeling via decreased myocardial apoptosis and inflammation in monocrotaline-induced rats. Eur. J. Pharmacol. 2018, 818, 525-533. [CrossRef] [PubMed]

29. Li, Y.; Wang, Y.; Li, Y.; Qian, Z.; Zhu, L.; Yang, D. Osthole attenuates pulmonary arterial hypertension in monocrotalinetreated rats. Mol. Med. Rep. 2017, 16, 2823-2829. [CrossRef] [PubMed]

30. Liu, J.C.; Wang, F.; Xie, M.L.; Cheng, Z.Q.; Qin, Q.; Chen, L.; Chen, R. Osthole inhibits the expressions of collagen I and III through Smad signaling pathway after treatment with TGF- $\beta 1$ in mouse cardiac fibroblasts. Int. J. Cardiol. 2017, 228, 388-393. [CrossRef] [PubMed]

31. Wang, J.; Fu, Y.; Wei, Z.; He, X.; Shi, M.; Kou, J.; Zhou, E.; Liu, W.; Yang, Z.; Guo, C. Anti-asthmatic activity of osthole in an ovalbumin-induced asthma murine model. Respir. Phys. Neurobiol. 2017, 239, 64-69. [CrossRef] [PubMed]

32. Sun, W.; Cai, Y.; Zhang, X.X.; Chen, H.; Lin, Y.D.; Li, H. Osthole pretreatment alleviates TNBS-induced colitis in mice via both cAMP/PKA-dependent and independent pathways. Acta Pharmacol. Sinica 2017, 38, 1120-1128. [CrossRef] [PubMed]

33. Wang, P.; Ying, J.; Luo, C.; Jin, X.; Zhang, S.; Xu, T.; Zhang, L.; Mi, M.; Chen, D.; Tong, P.; et al. Osthole promotes bone fracture healing through activation of BMP signaling in chondrocytes. Int. J. Biol Sci. 2017, 13, 996-1007. [CrossRef] [PubMed]

34. Zhang, Z.R.; Leung, W.N.; Li, G.; Kong, S.K.; Lu, X.; Wong, Y.M.; Chan, C.W. Osthole enhances osteogenesis in osteoblasts by elevating transcription factor osterix via cAMP/CREB signaling in vitro and in vivo. Nutrients 2017, 9, 588. [CrossRef] [PubMed]

35. Huang, T.; Dong, Z. Osthole protects against inflammation in a rat model of chronic kidney failure via suppression of nuclear factor- $\mathrm{k} B$, transforming growth factor- $\beta 1$ and activation of phosphoinositide 3-kinase/protein kinase B/nuclear factor (erythroid-derived 2)-like 2 signaling. Mol. Med. Rep. 2017, 16, 4915-4921. [CrossRef] [PubMed]

36. Yu, C.; Li, P.; Qi, D.; Wang, L.; Qu, H.L.; Zhang, Y.J.; Wang, X.K.; Fan, H.Y. Osthole protects sepsis-induced acute kidney injury via down-regulating NF-kB signal pathway. Oncotarget 2017, 8, 4796-4813. [CrossRef] [PubMed]

37. Li, Y.Q.; Wang, J.Y.; Qian, Z.Q.; Li, Y.L.; Li, W.N.; Gao, Y.; Yang, D.L. Osthole inhibits intimal hyperplasia by regulating the NF- $\mathrm{KB}$ and TGF- $\beta 1 / \mathrm{Smad} 2$ signalling pathways in the rat carotid artery after balloon injury. Eur. J. Pharmacol. 2017, 811, 232-239. [CrossRef] [PubMed] 
38. Miner, J.N.; Tan, P.K.; Hyndman, D.; Liu, S.; Iverson, C.; Nanavati, P.; Hagerty, D.T.; Manhard, K.; Shen, Z.; Girardet, J.L.; et al. Lesinurad, a novel, oral compound for gout, acts to decrease serum uric acid through inhibition of urate transporters in the kidney. Arthritis Res. Ther. 2016, 18, 214. [CrossRef] [PubMed]

39. Pharmaceutical and Medical Device Regulatory Science Society of Japan. Japanese Pharmacopoeia Seventeenth Edition (JP XVII); Jiho: Tokyo, Japan, 2016.

40. Pharmaceutical and Medical Device Regulatory Science Society of Japan. The Japanese Standards for Non-Pharmacopoeial Crude Drugs (Non-JP Crude Drug Standards); Yakuji Nippo Ltd. Company: Tokyo, Japan, 2015.

41. Kato, Y.; Yoshida, K.; Watanabe, C.; Sai, Y.; Tsuji, A. Screening of the interaction between xenobiotic transporters and PDZ proteins. Pharmaceu. Res. 2004, 21, 1886-1894. [CrossRef]

Sample Availability: Sample of the compound osthol is available from the authors.

(C) 2018 by the authors. Licensee MDPI, Basel, Switzerland. This article is an open access article distributed under the terms and conditions of the Creative Commons Attribution (CC BY) license (http://creativecommons.org/licenses/by/4.0/). 